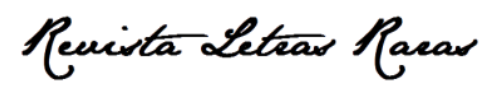

ISSN: 2317-2347 - v. 9, n. 3 (2020)

Todo o conteúdo da RLR está licenciado sob Creative Commons Atribuição 4.0 Internacional

\title{
A apoteose de Demerval Carmo-Santo
}

\section{Wellington Amancio da Silva*}

Mestre em Ecologia Humana pelo Programa de Pós-Graduação em Ecologia Humana no Campus VIII da Universidade Estadual da Bahia (PPGEcoH/UNEB). Professor Auxiliar da Universidade Federal de Alagoas-UFAL (2017-2018).

iD http://orcid.org/0000-0002-8226-7491

Recebido: 28 jan. 2020. Aprovado: 17 ago. 2020.

\section{Como citar este conto:}

SILVA, Wellington Amancio. A apoteose de Demerval Carmo-Santo. Revista Letras Raras, Campina Grande, v. 9, n. 3, p. 268-272, ago. 2020.

Em memória de Murilo Rubião

O ferrite do rádio estava quebrado, no centro do rolinho de fio de cobre. Não havia estações. Derreti a parafina com o ferro de soldar. Retirei a peça quebrada com cuidado, substituindo-a por uma nova. De imediato ouvi a estação, e seu locutor — de voz aveludada e grave - discorrendo sobre qualquer coisa. E assim, do nada, me surgiu vivalma. A música de fundo lembrava-me a infância, uma doce porção de memória (a casa pequena e limpa da minha tia, a camaradagem dos meus primos) iluminava-me tal a uma epifania. A voz de Dulce Pontes cantava "Lágrimas".

Me interrompeu o carteiro à porta da oficina. Não costumava receber cartas, porque não as envio a mais ninguém mais, ou sequer recebo encomendas, devido à minha crônica austeridade financeira. Aquele moço de farda amarela me entregou uma caixa de tamanho mediano, circundada de fita adesiva e selos. Assinei maquinalmente o recibo, e por esquecimento, quase não devolvi sua caneta. Voltei ao conserto do rádio e somente mais tarde abri aquela caixa primorosamente embalada. Continha um envelope ocre de feitura e acabamento perfeitos, e um 


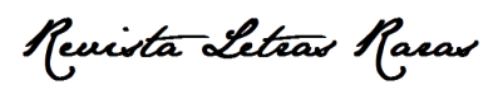

ISSN: 2317-2347 - v. 9, n. 3 (2020)

Todo o conteúdo da RLR está licenciado sob Creative Commons Atribuição 4.0 Internacional

paletó preto, belíssimo e novíssimo, cheirava à grife e a certo glamour. Eu desconhecia seu remetente.

No envelope uma carta em papel timbrado, de uma tal de Finis Nebulum Comporation até hoje não sei bem o que é isso. Em casa, percebi que o paletó preto era 42, eu visto 38. Com atenção redobrada, identifiquei na carta um convite para algum evento, no domingo da semana próxima. Detectei quatro recomendações, no meio do caos daquele português repleto de períodos e firulas. Confesso que estranhei bastante seu conteúdo, todavia, movido por enorme curiosidade, experimentei nos dias seguintes uma crescente ansiedade, que me afligia e me acirrada, à medida que o domingo se aproximava. A primeira recomendação, muito enfática, exigia-me um jejum de seis horas, antes do evento, que se iniciaria a partir das dezesseis horas. A segunda consistia de telefonar imediatamente a um número específico, após o recebimento da encomenda, para informar o meu endereço à empresa de táxi. A terceira enfatizava não levar nada, sobretudo dinheiro, joias ou o relógio, além do documento de identificação. A quarta recomendação solicitava que em hipótese alguma haveria acompanhantes, mesmo animal de estimação.

Li ainda: "Ilmo. Sr. Demerval Carmo-Santo. Comunicamos que vossa mercê é o felizardo de número 3.026, de uma extensa lista de pessoas estritamente escolhidas a participar do nosso Programa Filantrópico Finis Nebulum". Ah, eu me tornava ansioso ao imaginar o que me sucederia. Eu estava certo de que era coisa boa. E, enquanto pensava em reformar aquele paletó, descobri no cartão uma nota de rodapé, segundo a qual "em hipótese nenhuma a indumentária deverá ser modificada, sendo mister sua devolução consecutiva, após o evento".

Mais tarde, fui à padaria comprar brioches, croassãs e pães de alho. Levava comigo a tal carta, no bolso da calça, e, ao esperar ser atendido, dei mais uma espiada em seu texto. Acho que ninguém notou minha presença, na pequena fila, lendo aquela carta em papel espesso, em envelope ocre, muito embora o senhor Edvaldo Veneio (um funcionário público aposentado, poeta e dono de pequena funerária) saudasse-me com um atípico "boa noite" muito soado e longo, ao tocar em meu ombro direito e me olhar nos olhos com formalidade insossa.

Em casa, observei que dentro do envelope, havia uma frase de cor mais escurecida. Estava em latim, certamente. Eu não sabia absolutamente nada dessa língua morta, porque para mim, "Natura non contristatur" não se assemelha ao português, ou ao espanhol. Me aborreceu muito não saber se aquela frase fazia parte ou não do conjunto de informações do remetente. Eu estava meio frustrado por não saber o que significava. Se tenho interesse em algo e não o 


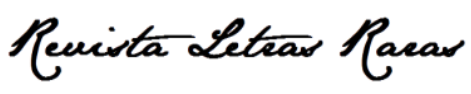

ISSN: $2317-2347-$ v. 9, n. $3(2020)$

Todo o conteúdo da RLR está licenciado sob Creative Commons Atribuição 4.0 Internacional

compreendo em sua totalidade, me angustio por demais da conta, sinto muita raiva, uma incapacidade humilhante, uma vontade de me estapear, uma comichão na alma. E eu presumia, com algum sarcasmo, o fato de um pedaço de papel mobilizar a alma e se objetar no corpo, tal uma dor, fazendo o coração acelerar daquele jeito. Um pedaço de papel sem fôlego, morto, mas que morde e arranha. $E$ a ansiedade e a raiva eram tantas, naquela noite, que deixei de lado os brioches, os croassãs e os pães de alho.

Infelizmente não havia naquele momento outra pessoa a quem pudesse consultar, a não ser Carlos. Ora, no dia seguinte (e não sei mesmo como suportei esperar pelo dia seguinte) procurei-o na redação de $O$ Eliseu, onde trabalhava. Infelizmente tive que mostrar-Ihe o convite. Em silêncio, deslizou o dedo indicador sobre o baixo relevo do timbre dourado, e em seguida sustentou o cartão sobre as duas mãos. Por uns instantes, infelizmente, ele correu aqueles olhos castanhos pelo papel de ótima gramatura, e consultou o fundo do envelope com um olho aberto. Por fim, respirou e disse, "tudo bem aqui. Não há nada de anormal, aqui. Não vejo problema, aqui. E a frase é mesmo do latim, e significa mais ou menos que a natureza não tem dó de ninguém, entende? Pode ser mesmo uma verdade".

Conhecia Carlos L. há mais de trinta anos, sempre com aquela testa ampla de quem segue perdendo a luta contra a calvície. No tempo em que andávamos juntos, ele dirigia-se a mim, com aqueles lábios comprimidos, finos e pálidos, e não havia uma só das minhas palavras que ele não sondasse negativamente, porque retrucava a mim, ainda que sutilmente. E era insuportável tê-lo por perto -era ele, porém, que vinha me visitar em minha casa, sempre interessado em meus livros. A última vez que nos encontramos, há uns cinco anos, estávamos no meio de extensa fila de candidatos para duas vagas de redator no $O$ Eliseu. Ele conquistou uma das vagas, porque era um dos poucos com diploma de doutorado e mais ou menos dez artigos publicados sobre Arthur Schopenhauer. Tornou-se editor chefe tempos depois.

Ele me devolveu a carta igualmente a quem devolver uma cédula de pouco valor. Perguntei-lhe o que, "de modo geral" poderia significar aquela carta:

— Não se preocupe, meu amigo - ele me disse —, nesta vida o caráter dúbio do ser é proposital e duradouro. Carta é carta.

Realmente, algumas vezes penso que a burocracia dos favores é um campo extenso e fértil para cultivar a má vontade. Até hoje penso que Carlos não tenha lido a carta, com o devido cuidado, e que nem ainda soubesse latim. E é em tais situações que vemos o apreço ou 0 


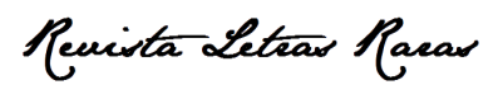

ISSN: 2317-2347 - v. 9, n. 3 (2020)

Todo o conteúdo da RLR está licenciado sob Creative Commons Atribuição 4.0 Internacional

desprezo do outro para conosco, e isto me dói o coração. Por que não se deteve mais um pouco em minha carta, de modo que demonstrasse gratidão pelos bons tempos de amizade? "Não há nada mais a considerar neste texto" - disse ele — "e agora preciso voltar imediatamente à edição de um artigo importante sobre Arthur Schopenhauer". Em seguida, ele pôs a minha carta no bolso, acho que sem intenções, e saiu. Eu precisei ir à sua banca de editor para resgatá-la. Devolveume rindo e desculpando-se. Fui-me embora dali.

Eu estava confuso. Mesmo a qualidade do papel e da impressão, a elaboração do texto de grande beleza, muito me convenciam de que eu não merecia tudo aqui, eu acho. Por causa destes últimos acontecimentos, me senti um tanto indeciso. Não estava convicto se deveria ir ao evento. Vesti mais uma vez aquele belo paletó. Ao espelho, me entristeci em demasia, quando me vi em uma roupa que não pertencia a mim, não fora confeccionada para mim, e suspeitei que não me permitiria habitá-la em paz. Mesmo assim e com algum esforço, considerei ir ao evento. Pensava no destino, tal como algo anteriormente escrito para nós. Entretanto, estando perdido 0 destino, cabe-nos encontrá-lo em algum lugar, conforme os êxitos das nossas pelejas - como dizia um pensador que não me lembro.

O táxi chegou precisamente às vinte uma hora e quinze minutos. Nunca antes vi aquele motorista. Aliás, um Chevrolet 2.0, branco e com faixas em azul e vermelho. Não era igual aos que circulavam por aqui. Saímos de imediato e não cumprimentamo-nos ou conversamos durante 0 trajeto. $O$ carro parou exatamente às vinte duas horas e cinquenta e oito minutos, em frente a uma igreja, que me lembro, talvez a visitei na infância, em um batismo. Saí, fechei a porta do táxi e ia abrir a carteira, quando ele ergueu o braço esquerdo à altura do peito, e com a mão aberta na vertical meneou para mim. Entendi como um "não", é claro. Me disse: "Está pago, senhor... Está pago...", e foi-se. Me senti aliviado, por não gastar dinheiro, é claro.

Olhei derredor. Na rua não havia transeuntes. Olhei para cima e a igreja a minha frente parecia erguer-se a uns oito metros de altura - sua grande porta era ampla e alta, de modo que a um só tempo umas quatro ou cinco pessoas poderiam atravessá-la de mãos dadas. Resolvi entrar, e uma alegria sem tamanho me visitou logo ao assentar o pé em seu piso. Por causa disso, permaneci à entrada por um momento, respirando fundo, e enquanto ali estive, sustentei como pude, em meu imo, aquela estranha alegria. Ao fundo, um padre mantinha-se estático, em sua túnica alva, frente ao altar. Percebi que algumas pessoas estavam sentadas nos primeiros bancos, próximos ao altar, e em silêncio. Logo quando chequei viraram-se à porta da igreja, e voltaram sua 
atenção para mim, eu acho. Entrei, e já no meio da igreja percebi que não somente elas me acompanhavam com o olhar atento, mas também o padre (penso que até a nave da igreja me ilhava). Eu ia me assentar atrás delas, quando o padre me disse: "Venha até aqui, meu filho". Tudo me parecia um acontecimento familiar. $E$ fui, tomado de um misto de alegria fervorosa e ansiedade desejosa, mas para quê? De imediato o padre abriu o alçapão de uma grande caixa dourada, em ângulos que me lembravam um ataúde, e em cima desta uma Minorah dourada, com sete lâmpadas alvas acesas. A caixa, me pareceu, de algum modo fazia parte do altar. O padre segurou a minha mão direita, e senti paz e quis chorar, mas me contive. Ergui a perna com cuidado (porque o terno e o sapato não eram meus) e ao adentrar a caixa, adveio-me um gosto esfumado de desmaio e outra vez aquela paz. Ah, eu entrei de bom grado, movido de grande felicidade. Nunca antes encontrei tamanha sorte, quando o tampo se fechou. 